\title{
THE PUBLIC USE TEST: WOULD A BAN ON THE POSSESSION OF FIREARMS REQUIRE JUST COMPENSATION?
}

\section{INTRODUCTION}

The most recent comprehensive estimate places the number of firearms in the United States in the area of 120 million.' Assuming an admittedly low value of $\$ 75.00^{2}$ is placed on each weapon, the present firearm stock is worth approximately nine billion dollars. If Congress or a state legislature banned possession of firearms, Congress and the courts would have to determine whether the ban came within the fifth amendment's command that private property not be "taken for public use, without just compensation." 3 This note attempts to answer that question. The high monetary stakes and the public's interest in gun legislation make this issue both important and timely. ${ }^{4}$

One commentator described the Supreme Court's approach to public taking law as "a welter of confusing and apparently incompatible results." 5 The Court itself recently said that it was "quite simply . . . unable to develop any 'set formula' for determining when 'justice and fairness' require that economic injuries caused by public action be compensated by the government." 6 The preliminary task of this note is to rationalize these "apparently incompatible results" into a unified taking theory. It is the authors' belief that the several tests which commentators have found to be useful in this area-the physical invasion test, the diminution in value test, the

Copyright $@ 1986$ by Law \& Contemporary Problems

1. J. Wright \& P. Rossi, Weapons, Crime, and Violence in America (Executive Summari), NATIONAL INSTITUTE OF JUSTICE 9 (1981).

2. J. Lewis, Gun Digest Book of Modern Gun Values (5th ed. 1985) (lists only a few guns at this value and virtually none at less).

3. U.S. Const. amend. V. The Supreme Court held that the fifth amendment was applied to the states via the fourteenth amendment in Chicago, B. \& Q. Ry. v. Illinois ex rel Drainage Comm 'rs, 200 U.S. 561 (1906). This note examines only how a state enactment would be evaluated under the Supreme Court's interpretation of the fifth amendment. How a gun ban would be evaluated under state law or a state constitution by a state court is beyond the scope of this note.

4. Admittedly, before the fifth amendment question is reached, any proposed law would have to pass scrutiny under the second amendment right to bear arms. See infia text accompanving notes $8-9,115$, and 169. For the purposes of this note, however, it will be assumed that gun control legislation would pass second amendment judicial scrutiny.

5. Sax, Takings and the Police Pouter, 74 Yale L.J. 36,37 (1964).

6. Penn Cent. Transp. Co. v. City of New York, 438 U.S. 104. 124 (1978); spe Ruckelshaus s. Monsanto Co., 104 S. Ct. 2862, 2874 (1984). 
noxious use test, and the police power test ${ }^{7}$ - can be unified in a coherent analysis. This analysis, which in general may be called the public use test, explains the major Supreme Court taking cases and is predictable and easy to apply.

The public use test can be summarized briefly. It applies a three-part analysis to any legislation challenged under the taking clause. All three parts of the test must be met before just compensation is required. The first part determines whether there has been an appropriation of property at all. Before the fifth amendment right to just compensation is triggered, private property must be appropriated. To answer this question, the Court has looked to whether the legislation has effected a physical invasion or outright appropriation of the property. When this has not been the case, the Court has looked to whether there has been a significant diminution in value or an interference with distinct, investment-backed expectations.

The second part of the test determines whether the government (be it federal, state, or municipal) has the constitutional power to enact the legislation. ${ }^{8}$ In the case of a federal law, the test is whether the enactment is within the federal government's enumerated powers or such implied powers as are necessary and proper to carry into effect the enumerated powers. In the case of a state or municipal law, the test is whether the enactment is within the ambit of the police power. If the act is not within the government's constitutional power, it is completely invalid. ${ }^{9}$

The third part of the test determines whether a valid appropriation of property requires compensation. Proceeding from the words of the amendment, which requires compensation only when private property is taken for "public use," the test distinguishes between general public welfare or evil-avoidance legislation and legislation in which the government intends for the public, or the government itself, to use the property.

This public use test illustrates the limited scope of the taking clause. At first glance, the public use limits on compensation seem unjust. Surely, when a regulation involves a widespread benefit, as does a zoning ordinance, or a

7. See, e.g. Michelman, Property, Utility, and Fairness: Comments on the Ethical Foundations of "Just Compensation" Law, 80 HaRv. L. Rev. 1165 (1967) (discussing "Physical Invasion," "Diminution in Value," and "Private Fault and Public Benefic"); Sax, supra note 5 (discussing "Invasion Theory." "Noxious Use," and "Diminution in Value").

8. It is in this portion of the analysis that a ban on the possession of firearms would be tested against the second amendment, an inquiry beyond the scope of this note.

9. If an action is found to be a "taking" and invalidated solely because of a failure to compensate, the government may have the option of either providing permanent compensation or rescinding its action. If the government chooses the latter course, it probably must nevertheless provide compensation for the "temporary taking" which has occurred. San Diego Gas \& Elec. Co. v. City of San Diego, 450 U.S. $621,658-59$ (1981) (Brennan, J., dissenting).

If an action - either a police power regulation or an eminent domain taking - is struck down because it goes beyond a government's legitimate powers, however, it cannot be cured by compensation and must be invalidated. In that case, it would be logically inconsistent to sav that a "temporary taking" had occurred during the period the invalid act was in effect. Rather. the property owner may have an action for damages under 42 U.S.C. $\$ 1983$, arguing that his property was taken without due process of law, thereby depriving him of his civil rights. Ser San Diego Gas $\dot{0}$ Eler. Co., 450 U.S. at 656 n.23 (Brennan, J., dissenting). 
regulation of firearms, the benefitted public as a whole should pay for whatever individual property rights are destroyed or diminished by the regulation. If one were to frame a new constitution, this sense of justice might be the starting point for a clause requiring compensation for diminished property rights whenever the diminution was caused by public welfare legislation. Our analysis is governed not by some hypothetical constitution, however, but by the fifth amendment, which requires compensation only in a limited number of situations. Moreover, almost any regulation tends to diminish someone's property or his liberty to use it. The government literally cannot afford to pay for every reduction in property values that it may cause. To quote Justice Holmes, "Government hardly could go on if to some extent values incident to property could not be diminished without paying for every such change in the general law." 10 For better or worse, the taking clause does not require compensation in all cases in which property interests are adversely affected. Rather, it draws the line where private property is taken "for public use."

This note discusses the three subsections of the tripartite analysis: (1) whether there is appropriation; (2) whether there is the power to appropriate; and (3) whether the appropriation is for the public use. Both the established tests and our public use test will then be applied to a federal ban on the possession of firearms.

\section{II}

\section{APPROPRIATION}

The beginning point for any analysis of a compensable "taking" is to examine whether property has been taken at all. Straightforward as the question seems, it has caused much controversy and confusion. This note divides the threshold inquiry into two tests. The first, the physical appropriation test, concerns instances in which it is clear that before the alleged taking the owner owned property but afterwards did not. The second, the diminution in value test, argues that government regulation is a taking when it so restricts the use of property that little of its value remains to the owner. Recently, this inquiry has been conducted by reference to an owner's "reasonable investment-backed expectations." "1

It bears emphasis that the inquiry into whether property has been appropriated remains only a threshold inquiry. Only when governmental action satisfies all three aspects of the public use test will a compensable taking result. Therefore, the cases discussed in this section may come down

10. Pennsylvania Coal Co. v. Mahon, 260 U.S. 393, 413 (1922). In addition. sce Justice Brandeis's famous dissent in the same case. Id. at 417 ("Every restriction upon the use of propert! imposed in the exercise of the police power deprives the owner of some right theretofore enjoyed. and is, in that sense an abridgment by the State of rights in property without making compensation.") (Brandeis, J., dissenting).

11. See Penn Cent. Transp. Co. v. City of New York, 438 U.S. 104, 124 (1978). 
on either side of the compensation issue, depending on how they fare under the remainder of the analysis.

\section{A. Physical Appropriation}

The physical appropriation test looks for an appropriation in its most literal sense: that is, a transfer of possession or ownership of property away from the owner. Such an appropriation of property obviously occurs where the government takes ownership of the property in its entirety, taking a fee simple interest in the whole. Also included, however, are those cases in which government forces the owner to destroy or abandon the property and those in which government appropriates only part of the owner's "bundle of rights." Courts sometimes characterize the latter situation as "physical invasion" of the property, because typically when only some of an owner's property rights are divested, the property is "invaded" by the rights of others in the form of an easement. ${ }^{12}$

Instances of total appropriation of property by the government are by their very nature easily determined, occasioning little controversy as to whether divestiture has occurred. Traditional condemnation of realty for construction of highways and other public works, confiscation of needed supplies or fuel in time of war, and forfeiture of property held illegally as contraband would all fall into this category. Similarly, forced destruction of property is fairly clear-cut. Examples include the ordered destruction of oil facilities to prevent their use by enemy forces, as was the case in United States $v$. Caltex (Philippines), Inc., ${ }^{13}$ and the destruction of unwholesome milk to prevent disease, as ordered in Adams $v$. Milwaukee. ${ }^{14}$ Disposal of property, such as handguns under the local ordinance in Quilici v. Village of Morton Grove, ${ }^{15}$ or liquor in the various prohibition cases, ${ }^{16}$ would also come under this heading.

The "physical invasion" situation has been somewhat more difficult to determine. In one of the most recent Supreme Court cases on the subject, Kaiser Aetna $v$. United States, ${ }^{17}$ the Court found that, although the government was not attempting to take a fee interest in the property in question, its proposal to open a private area to public access constituted a taking of part of the owner's valuable property right to exclude others. ${ }^{18}$ Kaiser Aetna, the lessee of a large Hawaiian estate that included both land and a large pond, developed the property into a residential and recreational subdivision called Hawaii Kai. As part of the development, Kaiser Aetna dredged the pond, constructed a marina, and created direct channels from the pond to a bay of the Pacific Ocean. The government claimed that since the pond had become a

12. See, e.g., Kaiser Aetna v. United States, 444 U.S. 164, 180 (1979).

13. 344 U.S. 149 (1952).

14. 228 U.S. $572(1913)$.

15. 532 F. Supp. 1169 (N.D. Ill. 1981), affd, 695 F.2d 261 (7th Cir. 1982), cert. denied. 464 U.S. $863(1983)$.

16. See, e.g., Samuels v. McCurdy, 267 U.S. 188 (1925); Mugler v. Kansas, 123 U.S. 623 (1887).

17. 444 U.S. 164 (1979).

18. Id. at 180 . 
navigable waterway, it was subject to the "navigational servitude" of the federal government. As a result, Kaiser Aetna could not deny the general public access to the marina. In his opinion for the Court, Justice Rehnquist stated that:

This is not a case in which the Government is exercising its regulatory power in a manner that will cause an insubstantial devaluation of petitioners' private property; rather, the imposition of the navigational servitude in this context will result in an actual physical invasion of the privately owned marina. ... And even if the Government physically invades only an easement in property, it must nonetheless pay just compensation. ${ }^{19}$

Because the government had taken an easement in the property, it had appropriated some of the owner's property rights, meeting the physical invasion test.

The airport-overflight cases also fall under the invasion analysis. In United States $v$. Causby, ${ }^{20}$ a chicken farmer whose property was directly under the flight path of military planes at a government airport complained that his farm was rendered useless because the noise, glare, and vibration so disturbed his chickens that they were killed by flying into the walls from fright. In finding a compensable taking, the Court relied on the theory that the flights constituted a physical invasion of Causby's airspace and as such created an easement across his property taken by the government. ${ }^{21}$ The Court relied upon Causby sixteen years later in Griggs $v$. Allegheny County ${ }^{22}$ to award compensation to a homeowner whose house was directly under the flight path of planes using the Allegheny County airport. Consistent with the physical invasion-easement analysis, property owners who have been similarly damaged by noise and vibration but whose properties were not directly under flight paths, and therefore not literally physically invaded, have been universally unsuccessful in obtaining condemnation awards. ${ }^{23}$

\section{B. Diminution in Value}

Although sometimes put forth as an entirely separate test for determining when there has been a compensable taking, the diminution in value test has been used mainly as a means of determining whether or not there has been a physical appropriation of property. The test is attributed to Justice Holmes's opinion in Pennsylvania Coal Co. v. Mahon, ${ }^{24}$ oft-cited for the proposition that "[o]ne fact for consideration . . . is the extent of the diminution. When it reaches a certain magnitude, in most if not in all cases there must be an exercise of eminent domain and compensation to sustain the act." 25 Holmes continued, "The general rule at least is, that while property may be regulated

19. Id.

20. 328 U.S. 256 (1946).

21. Id. at $265-67$.

22. 369 U.S. 84 (1962).

23. See Avery v. United States, 330 F.2d 640 (Ct. Cl. 1964); Batten v. United States, 306 F.2d 580 (10th Cir. 1962), cert. denied, 371 U.S. 955 (1963).

24. 260 U.S. 393 (1922).

25. Id. at 413 . 
to a certain extent, if regulation goes too far it will be recognized as a taking." reasoning in Pennsylvania Coal, ${ }^{27}$ and although the "diminution in value" test has never been determinative in a Supreme Court fifth amendment taking case, ${ }^{28}$ the test has persisted in dicta throughout the line of Supreme Court eminent domain cases.

For example, in the 1962 case of Goldblatt $v$. Hempstead, ${ }^{29}$ the Court discussed extensively the decrease in value of Goldblatt's property that would result from a zoning ordinance before dismissing it as inapplicable to the outcome of the case. Goldblatt involved a series of ordinances passed by the town of Hempstead which successively restricted the operation of Goldblatt's sand and gravel mine. The town brought suit to enjoin Goldblatt from mining, on the grounds that he was violating an ordinance which both prohibited mining below the water table and imposed an affirmative duty to refill the mine. Goldblatt's defense was based on the premise that the ordinance effectively prevented him from carrying on his business. The prohibition, therefore, so reduced the value of his property as to constitute a taking. The Court stated, however, that "the fact that it [the ordinance] deprives the property of its most beneficial use does not render it unconstitutional." 30 The clear implication of this statement should have been that the diminution in value test would never be dispositive of whether a taking had occurred. Nevertheless, Justice Clark's opinion continued (citing Pennsylvania Coal Co. v. Mahon ${ }^{31}$ and United States v. Central Eureka Mining Co., ${ }^{32}$ neither of which was ultimately decided by the test ${ }^{33}$ ):

This is not to say, however, that government action in the form of regulation cannot be so onerous as to constitute a taking which constitutionally requires compensation. . . . There is no set formula to determine where regulation ends and taking begins. Although a comparison of values before and after is relevant, it is by no means conclusive, see Hadacheck $v$. Sebastian, where a diminution in value from $\$ 800,000$ to $\$ 60,000$ was upheld. How far a regulation may go before it becomes a taking we need not now decide, for there is no evidence in the present record which even remotely suggests that prohibition of further mining will reduce the value of the lot in question. ${ }^{34}$

26. Id. at 415 .

27. See infra text accompanying notes 76-80.

28. E.g., Penn Cent. Transp. Co. v. City of New York, 438 U.S. 104 (regulation forbidding construction of office tower under lease agreement generating at least $\$ 3$ million annually); Goldblatt v. Hempstead, 369 U.S. 590 (1962) (regulation prohibiting continued excavation of sand and gravel mine); Village of Euclid v. Ambler Realty Co., 272 U.S. 365 (1926) (zoning law resulting in $75 \%$ diminution in value of property); Hadacheck v. Sebastian, 239 U.S. 394 (1915) (property worth $\$ 800,000$ for brickmaking reduced to $\$ 60,000$ if restricted for residential use); see Sax, supra note 5 , at 44 .

29. 369 U.S. 590 (1962).

30. Id. at 592 .

31. 260 U.S. 393 (1922).

32. 357 U.S. 155 ( 1958).

33. Pennsylvania Coal Co. v. Mahon is discussed infra, text accompanying notes 76-81. In Central Eureka Mining Co., the mine owner was prevented from operating his mine, clearly a substantial diminution in its value to him. Nevertheless, compensation was not awarded.

34. 369 U.S. at 594 (citations omitted). 
The Court apparently felt the need to pay lip service to the diminution in value test without actually relying on it.

The diminution in value test was once again considered by the Court in Penn Central Transportation Co. v. City of New York, ${ }^{35}$ although it was phrased in terms of "distinct investment-backed expectations."36 Justice Brennan's opinion in Penn Central provides an apt example of the confusion that arises when the Court continues to invoke a test yet does not rely on it. Early in the opinion, the Court stated: "Appellants concede that the decisions sustaining other land-use regulations, which, like the New York City law, are reasonably related to the promotion of the general welfare, uniformly reject the proposition that diminution in property value, standing alone, can establish a 'taking.' "'37 Although the Court thus initially rejected the diminution in value test, it nevertheless returned to the analysis later in its opinion:

We now must consider whether the interference with appellants' property is of such a magnitude that "there must be an exercise of eminent domain and compensation to sustain [it]" [citing Pennsylvania Coal]. That inquiry may be narrowed to the question of the severity of the impact of the law on appellants' parcel. ${ }^{38}$

The Court ultimately concluded that the damage to Penn Central was not sufficiently great to warrant compensation because the law did not interfere with the current use of the terminal and because the company had the ability to transfer its air rights over the terminal for value. ${ }^{39}$

Penn Central suggests that reciting the diminution in value/investmentbacked expectations analysis remains de rigueur. Similarly, Kaiser Aetna reiterated the test in its basic outline of taking analysis: "Rather, [this Court] has examined the 'taking' question by engaging in essentially ad hoc, factual inquiries that have identified several factors-such as the economic impact of the regulation, its interference with reasonable investment-backed expectations, and the character of the governmental action-that have particular significance." 40

If it is assumed, then, that the diminution in value test is alive and well, there are two alternative measures of appropriation: that is, either actual appropriation of the property or some portion thereof, or regulatory diminution of its value. In either form, a determination of government appropriation is the threshold inquiry in finding a compensable taking. However, contrary to Professor Michelman's assertion that "courts, while they sometimes do hold nontrespassory inquiries compensable, never deny compensation for a physical takeover," 41 even the physical appropriation test is not dispositive on the issue. Rather, this note shows that all three

35. 438 U.S. 104 (1978).

36. Id. at 124 " "The economic impact of the regulation on the claimant and, particularly, the extent to which the regulation has interfered with distinct investment-backed expectations are, of course, relevant considerations.").

37. Id. at 131 .

38. Id. at 136 .

39. Id. at 136-37.

40. 444 U.S. at 175.

41. Michelman, supra note 7 , at 1184 . 
requirements of the public use test must be met before compensable taking is found.

\section{III}

\section{Validity of Government AuThority}

The next step in the analysis of a compensable taking is to determine whether the act in question is a legitimate exercise of governmental power. States may exercise control over the property of their citizens through their sovereign powers of eminent domain, ${ }^{42}$ their power to tax, and their police powers.

Because the police power and the eminent domain power were traditionally considered to be distinct and mutually exclusive, ${ }^{43}$ distinguishing which power a state government was exercising became important in determining the legitimacy of a taking and the need for compensation. What emerged was the "police power" test, which held that a given governmental action was not a compensable taking simply because it was an exercise of traditional state police power. ${ }^{44}$ While the distinction between the police and eminent domain powers has become less important over time, the older case law is still cited in modern decisions, sometimes with confusing effect.

Whether characterized as an exercise of eminent domain, police power, or some other source of governmental authority, an appropriation of private property may be undertaken only if the benefit inures to the public as a whole. If the government attempts to appropriate property for an invalid public purpose or for an exclusively private purpose ${ }^{45}$ the attempt will be struck down as going beyond the government's legitimate sphere of activity, regardless of whether provision is made for compensation.

\section{A. The Police Power}

The classic definition of police power is that power of a state which is "exerted for the protection of the health, morals, and safety of the people." 46 These terms are used in their broadest possible compass: "Public safety, public health, morality, peace and quiet, law and order-these are some of the

42. See P. Nichols, The Power of Eminent Domain § $\$ 3,7,8$ (1909); J. Nowak, R. Rotunda \& J. Young, Constitutional Law 480-82 (2d ed. 1983).

43. See generally J. Nowak, R. Rotunda \& J. Young, supra note 42 , at 480 ; P. Nichols, supra note 42, $\S \S 17,18$; see also Michelman, supra note 7, at 1167-68.

44. See, e.g., 16A C.J.S. Constitutional Law $\$ 645$ (1956) ("The guaranty of due process of law prohibits the confiscation of property or the destruction of property without compensation, except where the property is taken or destroyed in a valid exercise of the general police power.") (emphasis added); authorities cited supra note 43; see also Fesjian v. Jefferson, 399 A.2d 861, 866 (D.C. 1979): Lamm v. Volpe, 449 F.2d 1202. 1203 (10th Cir. 1971) (dicta).

45. "It is fundamental in American jurisprudence that private property cannot be taken by the Government, national or state, except for purposes which are of a public character, although such taking be accompanied by compensation to the owner." Madisonville Traction Co. v. Saint Bernard Mining Co., 196 U.S. 239, 251 -52 (1905); see also Thompson v. Consolidated Gas Corp., 300 U.S. 55. 80 (1936); Nichols, The Meaning of Public l'se in the Laze of Eminent Domain, 20 B.U.L. REv. 615, 615 (1940)

46. Mugler v. Kansas, 123 U.S. 623,668 (1887). 
more conspicuous examples of the traditional application of the police power. . . Yet, they merely illustrate the scope of the power and do not delimit it." 47

In more concrete terms, the police power forms the basis for public welfare legislation, such as zoning laws and provisions for roads and schools; evil-avoidance legislation, such as prohibitions on noxious activities, unhealthy food, or dangerous products; and criminal laws prohibiting the use of property for illegal ends or the possession of unlawful weapons, drugs, or other items. It is clear that the police power suffices to justify government regulation, destruction, or appropriation of property. As the Supreme Court stated over fifty years ago in Miller $v$. Schoene, ${ }^{48}$ " [w] here the public interest is involved preferment of that interest over the property interest of the individual, to the extent even of its destruction, is one of the distinguishing characteristics of every exercise of the police power which affects property." 49

1. Police Power Test. Mugler v. Kansas ${ }^{50}$ is generally regarded as the beginning of modern compensation law, ${ }^{51}$ and it is, as well, the first case to hold that an exercise of the police power is not a compensable taking. Mugler had built an otherwise lawful brewery in 1877 , but in 1881 the state of Kansas passed a law stating that " $[t]$ he manufacture and sale of intoxicating liquors shall be forever prohibited in this State, except for medical, scientific, and mechanical purposes." 52 Mugler was indicted for both the sale of his beer and for the maintenance of a " "common nuisance, to wit:' his brewery." 53

The Court held that the prohibition on the use of his property as a brewery was not a taking because:

The exercise of the police power by the destruction of property which is itself a public nuisance, or the prohibition of its use in a particular way, whereby its value becomes depreciated, is very different from taking property for public use . . . In the one case, a nuisance only is abated; in the other, unoffending property is taken away from an innocent owner. ${ }^{54}$

Mugler thus became the precursor of a long line of cases holding that a government action would not be a fifth amendment taking if it fell within the realm of the police power.

2. Criminal Forfeiture. Criminal forfeiture of property is rarely analyzed as an eminent domain question, because the government's power to enact and enforce criminal laws comes within the police power. These laws can result in government appropriations of property if that property is contraband-stolen property, property used in commission of a crime, or property which it is

47. Berman v. Parker, 348 U.S. 26, 32 (1954); see Noble State Bank v. Haskell, 219 U.S. 104, 111

(1911) (police power includes righe to create bank guaranty fund to insure depositors).

48. 276 U.S. 272 (1928).

49. Id. at $279-80$.

50. 123 U.S. 623 (1887).

51. Sax, Takings, Private Property and Public Rights, 81 Yale L.J. 149, 149 n.3 (1971).

52. 123 U.S. at 624 .

53. Id. at 625 .

54. Id. at 669 . 
illegal to possess. Such appropriation of illegally possessed property was challenged as an uncompensated taking in Fesjian $v$. Jefferson. ${ }^{55}$ The District of Columbia handgun statute challenged in that case allowed only certain types of guns to be registered and, where registration was denied, required the guns to be surrendered, removed from the District, or otherwise eliminated. When a gun was voluntarily surrendered, no compensation was paid. In holding that the statute effected no compensable taking, the court stated that the fact "[ $t$ ]hat the statute in question is an exercise of legislative police power and not eminent domain is beyond dispute." 56 This distinction answered the taking question because, presumably, under the court's analysis, the two powers were mutually exclusive.

Criminal forfeiture can even extend to the property owner who is completely "innocent," in that he lawfully acquires property which subsequently becomes contraband per se through force of a statute outlawing possession and subjecting the property to forfeiture. Such was the case in Miller $v$. McLaughlin. 57 In that case, Nebraska had passed a statute prohibiting fishing with nets and making the possession of fishing nets unlawful, regardless of whether the nets were actually used. Miller's complaint was based on due process, rather than just compensation grounds; nevertheless, the Court's holding seems equally applicable to either point:

A State may regulate or prohibit fishing in its waters, and, for the proper enforcement of such statutes, may prohibit the possession within its borders of the special instruments of violation, regardless of the time of acquisition or the protestations of lawful intentions on the part of a particular possessor. ${ }^{58}$

Samuels $v$. McCurdy 59 is factually analogous. A Georgia statute made possession of alcoholic beverages illegal, thereby subjecting Samuels's liquor to seizure despite the fact that it had been lawfully purchased and brought into Georgia prior to the enactment of the statute. The reasoning behind the Court's decision was arguably flawed; 60 nevertheless, its holding - that the liquor could be taken without compensation because "[l]egislation making possession unlawful is . . . within the police power of the state as a reasonable

55. 399 A.2d 861 (D.C. 1979).

56. Id. at 866 .

57. 281 U.S. 261 (1930).

58. Id. at 264 (citations omitted). See also the opinion of the Nebraska Supreme Court in the case bclow: "A valid exercise of police power may affect or destroy values, where the use of property for its original purpose has become unlawful by a change in public policy as disclosed by a new statute. Prohibition thus affected property in breweries, but the legislation on that subject was nevertheless sustained. Mugler v. Kansas, 123 U.S. 623." Miller v. McLaughlin, 118 Neb. $174,178$. 224 N.W. 18, 21 (1929).

59. 267 U.S. 188 (1925).

60. Justice 'Taft's analysis was really an exercise in salami tactics: he reasoned that since under 1/ugler property can be successively regulated until its worth is negligible, "[w]hy should compensation be made now for the mere remnant of the original right if nothing was paid for the loss of the right to sell [the liquor], give it away or transport it?" 267 U.S. at 198. 
mode of reducing the evils of drunkenness" 61 -puts the case squarely in line with the other forfeiture cases. ${ }^{62}$

3. Noxious Use. Police power also includes the state's power to abate a nuisance, that is, to forbid the "noxious use" of property. Therefore, some cases have held that if a state confiscates or orders the destruction of a noxious use, it is necessarily using its police power and need not compensate. ${ }^{63}$ For example, in Lawton $v$. Steel, ${ }^{64}$ the Supreme Court upheld a New York statute that stated that any fishing net maintained in the water in violation of the fishing laws "is hereby declared to be, and is, a public nuisance, and may be abated and summarily destroyed by any person." 65 After asserting that the preservation of game and fish was within the proper domain of the police power, ${ }^{66}$ the Court found the summary abatement, without the fifth amendment protections of due process and just compensation, to be legitimate. ${ }^{67}$ In Adams $v$. Milwaukee, ${ }^{68}$ the destruction of potentially unwholesome milk was found to be the abatement of a public nuisance, and the owners of the milk were not compensated. Similarly, in North American Cold Storage Co. v. Chicago, ${ }^{69}$ the Court held that unwholesome food "should be summarily seized and destroyed to prevent the danger which would come from eating it."70

Many of the major fifth amendment cases have been categorized as nuisance cases: Miller $v$. Schoene ${ }^{71}$ involved the destruction of trees which were infected with cedar rust; Mugler $v$. Kansas ${ }^{72}$ involved the closure of a brewery; Hadacheck $v$. Sebastian ${ }^{73}$ involved the closure of a brickyard; and Goldblatt $v$. Hempstead ${ }^{74}$ involved closure of a gravel pit. The Court in Penn Central Transportation Co. v. New York pointed out, however, that many of these cases involved nothing noxious:

We observe that the uses in issue in Hadacheck, Miller, and Goldblatt were perfectly lawful in themselves. . . These cases are better understood as resting not on any supposed "noxious" quality of the prohibited uses but rather on the ground that the restrictions were reasonably related to the implementation of a policy-not unlike historic preservation-expected to produce a widespread public benefit and applicable to all similarly situated property. ${ }^{75}$

61. Id.

62. See, e.g. Calero-Toledo v. Pearson Yacht Leasing Co., 416 U.S. 663 (1974) (forfeiture of yacht transporting marihauna upheld).

63. See Michelman, supra note 7, at 1196-1201; Sax, supra note 5, at 48-50.

64. 152 U.S. 133 (1894).

65. Id. at 135 .

66. Id. at 138 .

67. Id. at 140 .

68. 228 U.S. $572.584(1913)$.

69. 211 U.S. 306 (1908).

70. Id. at 315 .

71. 276 U.S. 272 (1928).

72. 123 U.S. 623 (1887).

73. 239 U.S. 394 (1915).

74. 369 U.S. 590 (1962).

75. 438 U.S. at 133 n.30 
In Hadacheck and Goldblatt, for example, otherwise lawful uses of property were prohibited so that the land could be used for residential purposes. In both cases, the land was distant from residential property when the "noxious use" was begun. Clearly, the industrial uses of the property were originally lawful. The state merely made a choice between the value of the mine or the brickyard and the value of residential property and decided that residential property was more beneficial to the public. Nevertheless, regardless of whether the original use was prohibited because it was less beneficial to the public, it was within the state's police power to regulate.

\section{B. Eminent Domain and the Public Use Requirement}

While the scope of a government's police power has thus been viewed broadly to legitimize any act which accrues to the public benefit, a state's power of eminent domain was at first construed more narrowly. It only allowed property to be taken "for public use," which was defined more narrowly than the broader "public benefit."76 Pennsylvania Coal Co. v. Mahon ${ }^{77}$ provides an excellent example of the public use/public benefit distinction. In that case, Pennsylvania enacted a statute that prohibited mining of anthracite coal if it would cause subsidence of the surface at any location on which there were houses, factories, stores, public buildings, or streets. The state justified the act on standard police power grounds: that coal operations under the land carried out without preservation of the support of the surface constituted a "grave menace to the life, health and safety of the public." 78 The coal company, which had duly paid for not only the mineral rights but also the support rights which would have protected the surface, stood to lose the right

76. See, e.g., J. Gelin \& D. Miller, The Federal Law of Eminent Domain 12-15 (1982); 1 P. Nichols, The Law of Eminent Domain 128-36 (2d ed. 1917), and cases cited id. at 129 n.17; Nichols, supra note 45 , at $617-33$.

The distinctions made between "public use" and "public benefit" in some early state cases striking down a taking as beyond the eminent domain power should not be confused with the distinction which the test set out in this note makes between public use and public benefit. The earlier cases made the distinction as part of an inquiry into the legitimacy of the government's action (the inquiry in the second part of this note's public use test); in part three of the test proposed here, the distinction is made in determining which legitimate government acts require payment of compensation and which do not. Furthermore, the parameters of a defined "public use" have widened considerably over the years, wholly changing the distinction to be made between public use and public benefit. The law has generally progressed to a position which regards a government use of property for the public benefit-even a government sale of property to private parties for the public benefit-as a sufficient public use to legitimize a government taking. After accepting that government use can be equated with public use, so long as it is within the public benefit limitation, this note suggests a new distinction between that "use" and a government regulation which results in some "benefit" to the public without any literal use of the property by either the government or the public at large. For example, under the old use/benefit distinction, a state taking of land for urban renewal might be challenged because the public did not use the property in the same sense that it could use a highway; under the new use/benefit distinction, the government must offer compensation if it takes land for urban renewal, but is not required to compensate if it merely passes a regulation, such as a zoning ordinance, historic preservation law, or height restriction, from which the public passively benefits.

77. 260 U.S. 393 (1922).

78. Id. at 405 (argument for Pennsylvania). 
to mine substantial coal reserves and brought suit to enjoin enforcement of the statute on the ground that it was unconstitutional.

The Court struck down the statute on two distinctly different grounds. First, as applied to private property, the appropriation was not for a public purpose and could not be sustained under the government's police power. Second, as applied to public property, the taking for public use was constitutional but had to be accompanied by compensation. Justice Holmes arrived at the former conclusion by analyzing the statute as it applied to surface rights owned by a private individual who had his residence on the property. Holmes noted that because the individual homeowner did not own the support rights, a "source of damage to such a house is not a public nuisance even if similar damage is inflicted on others in different places. The damage is not common or public."79 Therefore, the Court ruled that the statute was not a legitimate exercise of governmental power: "[T] he statute does not disclose a public interest sufficient to warrant so extensive a destruction of the defendant's constitutionally protected rights [i.e., the coal company's right of ownership in the mineral and support rights]."80 In contrast, when the Court in dicta addressed the application of the statute to surface rights that were owned by the public, it found the government regulation to be legitimate, but required that it be done in the context of eminent domain proceedings. 81

Justice Holmes's analysis could have proceeded equally from a recognition that the statute in effect required a transfer of support rights-a legally recognized property interest-away from the owner, regardless of the value of those rights or the extent to which the statute decreased their value. Requiring such a transfer from one private party to another was beyond the power of the government. Requiring the transfer from a private owner to the government for the support of public roads and buildings was clearly a compensable taking.

\section{Rejection of the Police Power Test in Favor of A Public Use Test}

While the police power test holds that the police and eminent domain powers are mutually exclusive, an alternate branch of cases holds that the police power includes fifth amendment takings. For example, in Chicago, Burlington $\mathcal{E}^{\mathcal{O}}$ Quincy Railroad Co. v. Illinois ex rel. Drainage Commmissioners, ${ }^{82}$ the Court rejected the police power test, holding that the real distinction is between those regulations which take property for public use and those regulations which merely take property for the public good:

Private property cannot be taken without compensation for public use under a police regulation relating strictly to the public health, the public morals or the public

79. Id. at 413 .

80. Id. at 414 .

81. Id. at 415 .

82. 200 U.S. 561 (1906). 
safety, any more than under a police regulation having no relation to such matters, but only to the general welfare.

... The constitutional requirement of due process of law, which embraces compensation for private property taken for public use, applies in every case of the exertion of government power. If in the execution of any power, no matter what it is, the Government, Federal or state, finds it necessary to take private property for public use, it must obey the constitutional injunction to make or secure just compensation to the owner. ${ }^{83}$

More recently, the district court in Quilici v. Village of Morton Grove ${ }^{84}$ stated this view similarly:

It is well established that a Fifth Amendment taking can occur through the exercise of the police power regulating property rights. In order for a regulatory taking to require compensation, however, the exercise of the police power must result in the destruction of the use and enjoyment of a legitimate private property right. ${ }^{85}$

In 1954, the Supreme Court decided Berman v. Parker, ${ }^{86}$ which largely eliminated the need for any distinction between a state's police power and its eminent domain power. In that case, property owners challenged the District of Columbia Redevelopment Act of 1945 as effecting a taking of private property that was not for public use. The act set up a comprehensive urban renewal plan for Washington, D.C., under which the District of Columbia Redevelopment Land Agency was to acquire and assemble real property for redevelopment, sometimes by private parties. In deciding the case, the Court first noted that although the law was an act of Congress, Congress was acting in the capacity of a state government for the District of Columbia, ${ }^{87}$ and thus could exercise the police power normally reserved to the states. ${ }^{88}$ The Court found that in enacting the urban renewal plan, Congress was attempting to improve the general public welfare of the District of Columbia; such public welfare legislation was within the scope of the police power. The fact that the act provided for condemnation and compensation did not limit its scope under some narrower eminent domain power. Rather, the Court ruled, "Once the object is within the authority of Congress [acting as a state government], the right to realize it through the exercise of eminent domain is clear. For the power of eminent domain is merely the means to the end." 89

The effect of the Berman $v$. Parker holding was to expand the parameters of the eminent domain power to the outer limits of a state's police power to pass social legislation. Judicial review of this broad power would be extremely limited, since "[s]ubject to specific constitutional limitations, when the legislature has spoken, the public interest has been declared in terms wellnigh conclusive."'90

83. Id. at 592-93.

84. 532 F. Supp. 1169 (N.D. Ill. 1981), affd, 695 F.2d 261 (7th Cir. 1982), cert. demied. 464 U.S. 863 (1983).

85. Id. at 1183-84.

86. 348 U.S. 26 (1954).

87. Id. at 31 .

88. Id. at 32 .

89. Id. at 33 .

90. Id. at 32 . 
Such an interpretation was explicitly affirmed in 1984 in Hawaii Housing Authority $v$. Midkiff, ${ }^{91}$ in which Justice O'Connor flatly stated, "The 'public use' requirement is ... coterminous with the scope of a sovereign's police powers."92 She went on to note that "where the exercise of the eminent domain power is rationally related to a conceivable public purpose, the Court has never held a compensated taking to be proscribed by the Public Use Clause."93

Midkiff illustrates how far the Court has been willing to go to find a public use justifying a taking. The act under challenge in that case was the Hawaii Land Reform Act of 1967, passed to alter the oligopolistic pattern of land ownership in Hawaii. The first Polynesian settlers in Hawaii had established a feudal system of land ownership in which certain subchiefs held large tracts of land at the will of the islands' high chief. In the mid-1960's, the Hawaii legislature found that the pattern of land ownership which had evolved from the original feudal system remained one of concentration of land in the hands of a few owners. Therefore, the legislature set up a procedure whereby tenants wishing to purchase the property on which they lived could ask the Hawaii Housing Authority (HHA) to condemn the property, pay market price to the owners, and sell it to them. The HHA was authorized to lend such purchasers up to ninety percent of the purchase price. ${ }^{94}$ When the lands of certain landowners were threatened by condemnation under the scheme, the owners filed suit to enjoin the act's enforcement, arguing in part that the taking was not one "for public use." Their argument, as articulated by the Ninth Circuit Court of Appeals, was that the act was "a naked attempt on the part of the state of Hawaii to take the private property of A and transfer it to B solely for B's private use and benefit.'”95 The Supreme Court disagreed with that characterization. While noting that "one person's property may not be taken for the benefit of another private person without a justifying public purpose, even though compensation be paid," 96 the Court found sufficient public use to uphold the Land Reform Act. ${ }^{97}$ Because of its holding that a state's police power and its eminent domain power are identical in scope, the Court's decision inevitably followed from its conclusion that "[r]egulating oligopoly and the evils associated with it is a classic exercise of a State's police powers."98

91. 104 S. Ct. 2321 (1984).

92. Id. at 2329.

93. Id. at 2329-30. Although Justice O'Connor attempted to distinguish Thompson : Consolidated Gas Utils. Corp., 300 U.S. 55 (1937), as invalidating an uncompensated taking, 104 S. Ct. at 2330, compensation would not have changed the Court's holding in that case. Sep Thompson. 300 U.S. at 80. Likewise, under Justice Holmes's analysis of Pennsylvania Coal Co. v. Mahon, 260 [i.S. 393 (1922), a compensation provision would not have saved the Pennsylvania statute from the Court's ruling of invalidity as applied to private parties. See supra text accompanying notes $76-81$.

94. Hawaii Housing Auth. v. Midkiff, 104 S. Ct. at 2325-26.

95. Midkiff v. Tom, 702 F.2d 788, 798 (9th Cir. 1983), rei id sub nom. Hawaii Housing Auth. v. Midkiff, 104 S. C. 2321 (1984).

96. Hawaii Housing Auth. v. Midkiff, 104 S. Ct. at 2329.

97. Id. at 2330.

98. Id. 
While Pennsylvania Coal Co. v. Mahon ${ }^{99}$ is never mentioned in the opinion, it seems clear that Mahon's narrow view of what constitutes a public purpose would be rejected under the Midkiff analysis. Under modern doctrine, the Court would surely find the public interest in safety, furthered by a transfer of support rights from the mining company to the private landowners living above the mine, sufficient to uphold the taking if, of course, compensation were provided. ${ }^{100}$

\section{Federal Powers}

Analyzing the legitimacy of government appropriations or regulations of property poses special problems in the case of the federal government, because it is a government of limited powers. ${ }^{101}$ First, nothing in the Constitution explicitly confers a power of "eminent domain" on the federal government; the words are never used. Rather, the only relevant language is that of the fifth amendment, requiring that property not be "taken" for public use without just compensation. Although the power of eminent domain arguably could be inferred from this language, such an inference is inconsistent with the general notion that all powers not expressly granted to the federal government are reserved to the states. Furthermore, the Bill of Rights is generally regarded as limiting, rather than expanding, the government's powers. Therefore, the better interpretation is that the fifth amendment imposes limitations on government "takings" that are necessary and proper means of carrying out some enumerated power. ${ }^{102}$ For example, in Kaiser Aetna v. United States, ${ }^{103}$ the Court analyzed the government's taking as an exercise of commerce power: "In light of its expansive authority under the Commerce Clause, there is no question but that Congress could assure the public a free right of access to the Hawaii Kai Marina if it so chose." $10+$ This justification under the commerce power did not provide the answer to the Court's inquiry into the compensation issue, however. ${ }^{105} \mathrm{In}$ fact, it is clear that the thesis of the police power test-that if a government act can be subsumed under some other general legislative power, it is not an eminent domain "taking"- cannot be valid at the federal level. Compensable takings will always be the means to an end justified by some other power.

Nor can the scope of the federal taking power be analyzed under the police power limitations espoused in Berman v. Parker ${ }^{106}$ and Hawaii Housing Authority

99. 260 U.S. 393 (1922). For a discussion of Mahon, see supra text accompanying notes 76-81.

100. See supra text accompanying notes 76-81.

101. Nichols, supra note 45, at 634-39. See generally J. Nowak, R. Rotunda \& J. Young, supra note 42 , at 121 .

102. J. Nowak, R. Rotunda \& J. Young, supra note 42, at 480; 2 A P. Nichols. Nichols on Eminent Domain $\$ 7.14$ (2) (J. Sackman rev. 3d ed. 1983); P. Nichols, supra note 42, \$ 23; spe. e.g.. United States v. Gettysburg Elec. Ry., 160 U.S. 668, 681 (1896).

103. 444 U.S. 164 (1979).

104. Id. at 174.

105. Id.

106. 348 U.S. 26 (1954); see supra text accompanying notes 86-90. 
v. Midkiff. ${ }^{107}$ The simple reason is that there is no general federal police power. ${ }^{108}$ If Congress has jurisdiction to legislate pursuant to one of its enumerated powers, however, it may enact laws that resemble police power regulations. ${ }^{109}$ "It is no objection to the exercise of power of Congress that it is attended by the same incidents which attend the exercise of the police power of a State."110 The most common jurisdictional hook is the commerce power, ${ }^{11}$ but the taxing power is also often used. 112

Therefore, any limitation on federal taking power must come either from limitations on the enumerated powers or from some remaining vitality of the "public use" requirement of the fifth amendment. For example, in the context of gun control legislation, Congress would have to first justify legislation under some enumerated power, most likely the commerce power. Given the expansive interpretation that has been accorded the commerce power, such police power type legislation would undoubtedly withstand judicial scrutiny. The leading case justifying federal regulation of health, safety, and morals under Congress' power to regulate interstate commerce is Champion v. Ames (the Lottery Case). ${ }^{13}$ In that case, the Court supposed that Congress enacted federal legislation prohibiting the sale of lottery tickets through interstate commerce because the tickets were nuisances injurious to public morality. ${ }^{14}$ Despite the apparent attempt by Congress to exercise "police power," the Court upheld the legislation as supported by the commerce clause.

The second amendment might also circumscribe federal gun legislation efforts. ${ }^{115}$ If it were found that a ban on private possession of firearms violated the second amendment, such a government act would of course be invalidated, regardless of whether compensation was provided.

Finally, the "public use" requirement of the fifth amendment could still retain some meaning independent of Congress' power to achieve the goal effected by a taking. For example, the public use limitation on federal takings

107. $104 \mathrm{~S}$. Ct. 2321 (1984); see supra text accompanying notes 91-100.

108. J. Nowak, R. Rotunda \& J. Young, supra note 42 , at 480 . Therefore, Congress must rely on an enumerated power, such as the commerce power, to establish jurisdiction for federal criminal laws. See id. at 168-69.

109. See Hodel v. Virginia Surface Mining \& Reclamation Ass'n, 452 U.S. 264, $291-92$ (1981): Brooks v. United States, 267 U.S. 432, 436-39 (1925); Hamilton v. Kentucky Distilleries \& Warehouse Co., 251 U.S. 146, 156 (1919). With regard to the power to regulate liquor the Hamilton Court held:

That the United States lacks the police power, and that this was reserved to the States by the

Tenth Amendment, is true. But it is none the less true that when the United States exerts any of the powers conferred upon it by the Constitution, no valid objection can be based upon the fact that such exercise may... tend to accomplish a similar purpose.

251 U.S. at 156. See also Daut v. United States, 405 F.2d 312, 316 (9th Cir. 1968), rert. denied. 402 U.S. 945 (1971); Speert v. Morgenthau, 116 F.2d 301,305 (D.C. Cir. 1940); Sax, supra note 5, at 36 n.6.

110. FPC v. Natural Gas Pipeline Co., 315 U.S. 575, 582 (1942).

111. See, e.g., Controlled Substances Act of 1970, 2 i U.S.C. $\$ 801$ (3) (1982).

112. See, e.g., Internal Revenue Code of 1954, 26 U.S.C. $\$ \S 5801-5872$ (1982) (taxes on fircarms).

113. 188 U.S. 321 (1902).

114. Id. at $355-56$.

115. See generally United States v. Miller, 307 U.S. 174 (1939) (discussing but rejecting second amendment challenge to firearm regulation). 
was discussed in Monsanto Co. v. EPA. ${ }^{116}$ In that case, Monsanto challenged amendments to the Federal Insecticide, Fungicide and Rodenticide Act (FIFRA) which required it to disclose certain trade secrets in applications submitted to the Environmental Protection Agency (EPA). The district court found that these requirements would disclose Monsanto's data to its competitors, so that "[i]n effect, the 1978 amendments to FIFRA g[a]ve Monsanto's competitors a free ride at Monsanto's expense." 117 Monsanto argued that the amendments effected a taking of its property (trade secrets) for a private, rather than public, use and were beyond the power of Congress. ${ }^{118}$ The Supreme Court found that there was in fact a taking, but that the regulation sufficiently benefitted the public interest in competition to come within the public use requirement. ${ }^{19}$ Astonishingly enough, the Court's rationale was that "[s]uch a procompetitive purpose is well within the police power of the Congress." 120 Despite the arguable inaccuracy of this statement, it does seem clear that a federal taking would not be limited any more than a state taking by the public use requirement. Rather, such an act will be upheld "[s]o long as the taking has a conceivable public character."121

Public Use

The first two parts of this taking analysis have discussed what kinds of regulations are valid appropriations of private property. As was shown in the last section, any appropriation of property by government must benefit the public to be valid. For compensation to be required, validly appropriated property not only must benefit the public, but also must actually be used by the public or the government. ${ }^{122}$ The present section outlines what constitutes a public use.

The public use test is derived from the language of the fifth amendment: "Nor shall private property be taken for public use, without just compensation." 123 The essential distinction which this test makes is between taking property for public use, which is a compensable act, and taking property for any other purpose, which is not.

Compensable public use regulations are inspired by the same desire for public welfare that characterizes other valid appropriations. Certainly, an appropriation of property to build a highway or a town hall is intended to benefit the public. It is the nature of the use, however, and not the resulting benefit to the public, which triggers the payment of compensation. In both of

1 16. 564 F. Supp. 552, 566-67 (E.D. Mo. 1983), vacated sub nom. Ruckelshaus v. Monsanto Co.. 104 S. Ct. 2862 (1984).

117. 564 F. Supp. at 566.

118. See Ruckelshaus v. Monsanto Co., 104 S. Ct. at 2871.

119. Id. at $2879-80$.

120. Id. at 2880 .

121. Id. at 2879 .

122. See supra note 76 .

123. U.S. Const, amend. V (emphasis added). 
these situations, the public has used the property in the plain meaning of the word "use." In the case of the highway the public will drive over the appropriated land. In the case of the town hall the government (and derivatively the public) will occupy the property.

In contrast, a public "use" does not exist where the public passively benefits from the appropriation. There was no use, for example, of the cedar trees which were destroyed in Miller $v$. Schoene. ${ }^{124}$ Indeed, the felled trees were explicitly left to Miller, to be used by him as he saw fit. ${ }^{125}$ Similarly, if a statute banned the possession of firearms, but created an exception for guns which were rendered permanently inoperative, ${ }^{126}$ the public would not use the inoperative weapons. In these situations, the public does not use validly appropriated property; thus the fifth amendment does not require compensation.

The clearest example of the public use principle can be seen in the imminent disaster cases in which the government used its emergency power. In the most famous of these cases, United States $v$. Caltex (Philippines) Inc., ${ }^{127}$ the government destroyed oil reserves and the facilities in which they were stored because the facilities were under imminent threat of being captured by the Japanese. Prior to the destruction, the Army requisitioned a major share of the oil reserves. ${ }^{128}$ The government paid for the petroleum but refused to pay for the destroyed facilities. ${ }^{129}$ The Court upheld the refusal under the theory that the destruction of private property in war must be "borne by the sufferers alone." 130

Although the Court did not rely on a public use rationale, it seems clear that the test can easily explain the Caltex result. The oil reserves that the Army requisitioned were taken for government use and thus would be compensable losses under the public use test. The oil facility was destroyed in an act of evil-avoidance and as such resulted in no public or government use. As a result, that destruction and all other "injury of private property in battle" 131 were noncompensable losses.

Although the Court has never explicitly adopted the public use test, it used a similar analysis to bolster its judgment that the landmark preservation law in Penn Central Transportation Co. v. City of New York ${ }^{132}$ did not effect a compensable taking. Penn Central involved a New York City ordinance which prevented certain kinds of structural alterations to buildings which were determined to have historic and architectural value. The Penn Central Transportation Company wished to build an office tower over Grand Central

124. 276 U.S. $272,277(1928)$.

125. Id.

126. See, for example, the ordinance at issue in Quilici v. Village of Morton Grove, $532 \mathrm{~F}$. Supp.

1169,1171 (N.D. Ill. 1981), affd, 695 F.2d 261 (7th Cir. 1982), cert. denied. 464 U.S. 863 (1983).

127. 344 U.S. 149 (1952).

128. Id. at 150 .

129. Id. at 151

130. Id at 153 .

131. Id.

132. 438 U.S. 104 (1978). 
Station but was prevented from doing so by the ordinance. It therefore sued New York City for the loss in value to its property that resulted from the restriction. ${ }^{133}$ Among a loosely structured series of holdings which will be discussed more fully below, the Court found that the restriction did not result in government or public use:

[T] he Landmarks Law neither exploits appellants' parcel for city purposes nor facilitates nor arises from any entrepreneurial operation of the city. ... The Landmarks Law's effect is simply to prohibit appellants or anyone else from occupying portions of the airspace above the Terminal, while permitting appellants to use the remainder of the parcel in a gainful fashion. This is no more an appropriation of property by government for its own use than is a zoning law . . . ${ }^{134}$

In Penn Central the Court thus distinguished, as does the test proposed in this note, between mere passive benefit to the public and active use by the public or government. Only the latter requires compensation.

The public use portion of the test proposed here bears some similarity to the test which Professor Sax has set forth. Sax distinguishes between regulations that enhance the government's "enterprise capacity" and regulations that are enacted pursuant to the government's "arbitral capacity." 135 He defines enterprise capacity as "the economic function of providing for and maintaining the material plant, whether that be the state capitol or a [state-run] retail liquor store."136 In contrast, the government acts in its arbitral capacity when it regulates to avoid evil or to promote the public welfare by reconciling differences among private interests in the community. It is acting in this capacity when "it says, as between neighbors, that one fellow must cease keeping pigs in his backyard or must cease making bricks at a certain location." 137 The rule that Sax proposes is that when government appropriates property in its enterprise capacity, compensation is required. ${ }^{138}$ "But," Sax writes, "losses, however severe, incurred as a consequence of government acting merely in its arbitral capacity are to be viewed as a non-compensable exercise of the police power." 139

The differences between the Sax test and the test proposed in this note are more cosmetic than substantive. Whereas Sax wishes to incorporate new vocabulary into a field already overflowing with terms of art (noxious use, diminution in value, etc.), this note's public use terminology returns to the words used in the amendment itself. Further, whereas Sax dismisses the earlier tests as generally unhelpful, ${ }^{140}$ the public use test incorporates them in a systematic way and thus comes closer to established doctrine. ${ }^{141}$

133. Id. at 116-19.

134. Id. at 135 (emphasis added).

135. Sax. supra note 5 , at 62-63.

136. Id. at 62.

137. Id. at 62-63.

138. Id. at 63 .

139. Id.

140. Id. at 37

141. These differences will result in different outcomes in some situations. Because the Sax test docs not require that there be an initial finding of appropriation (the first step of the public use test). it would compensate the landowners in the overflight cases where property was not directly below 
The public use test also has the advantage of explaining why the more traditional tests-physical invasion, diminution in value, noxious use, and police power-work or do not work in a given case. The physical appropriation test seems to work well because government does in fact often use the property which it has appropriated. On the other hand, the numerous exceptions to the physical appropriation rule can only be explained by testing them against the remaining two inquiries of the public use test. For example, the owners of the fishing nets in Miller $v$. McLaughlin ${ }^{142}$ and the owner of the liquor in Samuels $v$. McCurdy ${ }^{143}$ both suffered confiscation of their property by the government without payment of compensation. The governmental acts in both cases were justified as valid police power, evil-avoidance legislation. The government's confiscation, however, was not undertaken with the purpose of acquiring property with the intent to use it. It is not clear how the government disposed of the appropriated property-perhaps the nets and liquor were destroyed-but in neither case was the property reemployed by the public.

The public use requirement similarly explains the disparity in the airport overflight cases. In United States v. Causby ${ }^{144}$ and Griggs v. Allegheny County, ${ }^{145}$ the property owners' airspace was actually occupied, or used, by the airplanes. ${ }^{146}$ That the degree of damage to property owners is not particularly determinative of a "taking" is evidenced by the cases holding that neighboring property owners, who may have been identically damaged, are not entitled to compensation. ${ }^{147}$ One may flinch at the seeming injustice of

the flight paths. Sax, supra note 5, at 67-69. These owners were damaged by vibrations and noise but the government did not actually take an interest in their airspace. Although justice would at first seem to require compensation, the taking clause does not require it because there was no appropriation.

This note's tripartite analysis also explains another line of cases, the outcome of which Sax admits does not fit within his scheme. These are cases in which the government required the railroads to build grade crossings where the railroad right-of-way crossed either a public highway or watercourse. See id. at 70; see, e.g., Atchison, T. \& S. F. Ry. v. Public Util. Comm'n, 346 U.S. 346 (1953). The courts have consistently held that the railroads could be required to bear the entire burden without any government compensation. Sax, supra note 5, at 70. Under the Sax test, compensation should be required, since the government is engaged in its enterprise capacity of improving the public highways. Id.

What Sax fails to note is that railroad rights-of-way are specialized interests in land that are not accorded conventional treatment. For example, the Supreme Court upheld a statute requiring a railroad to bear all the costs of destroying old bridges and constructing new ones over a watercourse in Chicago, B. \& Q. Ry. v. Illinois ex rel. Drainage Comm'rs, 200 U.S. 561 (1906). The Court characterized the watercourse as a natural easement. Id. at 587. It then reiterated with approval the Illinois Supreme Court's finding that at common law a railroad which crossed a watercourse or highway had to build and maintain the railroad so as to accommodate the easement "for all future time." $I d$. If the easement required maintenance to accommodate all future use, then nothing was appropriated when the government required the bridge to be rebuilt. The railroad crossing cases, therefore, come to the correct result under the tripartite public use test.

142. 281 U.S. $261(1930)$.

143. 267 U.S. 188 (1925).

144. 328 U.S. 256 (1946).

145. 369 U.S. 84 (1962).

146. See supra text accompanying notes $20-23$

147. See Avery v. United States, 330 F.2d 640 (Ct. Cl. 1964); Balten v. United States, 306 F.2d 580 (10th Cir. 1962), cert. denied, 371 U.S. 955 (1963). 
such distinctions, but it is clear that the fifth amendment draws the line between properties actually used and those "merely" damaged.

The public use test also helps explain why the diminution in value argument has been so universally unsatisfactory. Simply put, it would be a rare instance where it could be shown that the government used property which it had not in fact taken title to or possession of, but rather had merely regulated in a way that diminished its value to the owner.

The diminution in value argument has frequently been rebutted by the police power and noxious use tests. In these instances, the Court will uphold a regulation that severely diminishes property values on the grounds that the regulation is a valid exercise of police power. While no doubt true, the argument is singularly unhelpful as a test. In Mugler $v$. Kansas, ${ }^{148}$ for example, the closing of Mugler's brewery surely decreased the value of his property, since presumably the brewery could not have been put to alternative uses without substantial investment, if indeed it could be put to alternative uses at all. The closing of the brewery was just as surely valid as a police power means to abate a nuisance. The compensation issue, however, should have been determined not by whether the public thereby benefitted from the brewery closing, but by whether the public in fact actually used the property.

In those evil-avoidance cases in which the property is actually destroyed, such as the spoiled milk case, Adams $v$. Milwaukee, ${ }^{149}$ clearly the first test of appropriation is met. The property owner owned the milk before the government action; afterward he did not. The second question, the power of the government to act, is similarly met by the Court's finding that the destruction of the milk was a valid means for the government to protect the public. However, the third inquiry, requiring public use, is not satisfied since the public obviously could not make use of the milk which no longer existed. In contrast, if the government had tried to culture antibodies in the spoiled milk, compensation would clearly have been required.

Penn Central Transportation Co. v. City of New York ${ }^{150}$ serves as a useful illustration of how the public use test can be applied more rationally than the current taking tests. Justice Brennan's majority opinion in Penn Central actually encompassed all three of the test's inquiries, although not in the order or relationship suggested in this note. The opinion clearly examined the legitimacy of the New York City Landmarks Law, which Penn Central attacked as arbitrary and inequitable in its application. ${ }^{151}$ In upholding the law, the Court cited the finding of the New York Court of Appeals that the implementation of the objectives of the Landmarks Law constituted an "acceptable reason for singling out one particular parcel for different and less favorable treatment."152

148. 123 U.S. 623 (1887).

149. 228 U.S. 572 (1913).

150. 438 U.S. 104 (1978).

151. Id. at $131-33$.

152. 42 N.Y.2d 324, 330, 397 N.Y.S.2d 914, 918, 366 N.E.2d 1271, 1274 (1977), quoted in Pen! Central, 438 U.S. at 132 n.28. 
The Court also found that the government had not appropriated the property for its own use. ${ }^{153}$ According to the public use test, the inquiry would end there, for the Court's holding that no compensation was necessary would have been fully justified at that point. But the opinion then proceeded to look at the public use test's threshold level question of appropriation, in terms of the diminution of value test:

Rejection of appellants' broad arguments is not, however, the end of our inquiry, for all we thus far have established is that the New York City law is not rendered invalid by its failure to provide "just compensation" whenever a landmark owner is restricted in the exploitation of property interests, such as air rights, to a greater extent than provided for under applicable zoning laws. We now must consider whether the interference with appellants' property is of such magnitude that "there must be an exercise of eminent domain and compensation to sustain it." 154

The Court then found that Penn Central was not sufficiently damaged to justify compensation. However, the opinion emphasized that the holding was based on the present record, which showed "Penn Central's present ability to use the Terminal for its intended purposes and in a gainful fashion." 155 The Court implied that if the Terminal had ceased to be "economically viable," compensation might have been appropriate. ${ }^{156}$

The idea that compensation to a given property owner affected by a government regulation should depend on the severity of the regulation's impact on his parcel misinterprets the law of eminent domain. Of course, the severity of the harm is relevant in determining the amount of a compensation award, once it is determined that compensation is to be paid. But an act of government is either an eminent domain taking or it is not; its characterization as a taking should not vary according to the resulting financial condition of the property owners affected. Indeed, an argument can be made that once the government has determined that a property owner is entitled to compensation, it denies equal protection of the laws if it fails to compensate all property owners affected by the government act in question, even if they are damaged to a lesser degree.

The public use test proposed by this note avoids these inquiries and focuses, instead, on the factors that are truly relevant: (1) Has there been an appropriation? (2) Is the appropriation a legitimate exercise of power? and (3) Does the public actually use the appropriated property?

\section{Firearms and Taking Law}

Before analyzing a ban on the possession of firearms under this three-part test, it will be useful to consider whether the ban would require just compensation under the more traditional tests: the physical appropriation

153. 438 U.S. at 135 ; see supra text accompanying note 134.

154. 438 U.S. at $135-36$.

155. Id. at 138 n. 36 .

156. Id. 
test, the diminution in value test, the police power test, and the noxious use test.

Insofar as a statute would require firearm owners to surrender their weapons to the government, the physical appropriation test would be met. The owner would have had a fee simple interest in the weapon before the law was passed and no interest whatsoever after the weapon was turned in. Under this test, therefore, compensation would be required.

It is likely, however, that a law would be more narrowly drawn. For example, the ordinance passed by the Village of Morton Grove forbade the possession of handguns within the village unless (a) the gun was rendered permanently inoperative; (b) the owner was a licensed gun collector, peace officer, prison official, or member of the armed forces; or (c) the gun was kept at a gun club. ${ }^{157}$ Each of these situations shifts the analysis from physical appropriation to diminution in value.

Since the Supreme Court has apparently never actually found there to be a taking under this test, it is unclear how much of a diminution would cause compensation to be required. If the Morton Grove alternatives were incorporated into a federal ban, the greatest diminution would occur if the gun were rendered permanently inoperative. In that case, the gun would have value only as a collectible or antique. Under Goldblatt $v$. Hempstead, however, the fact that the law deprives property of its most beneficial use does not require that compensation be paid. ${ }^{158}$ The next greatest diminution would occur if the owner were forced to keep the gun at a club. The weapon could still be used, but not in one's home. Again, the Goldblatt holding would uphold the regulation without compensation.

If a firearm ban were drafted to prohibit ownership or possession without providing for government confiscation, the diminution in value test might indeed be met, since an owner would be deprived of all rights in his gun. The district court that considered the Morton Grove ordinance avoided this issue by pointing out that guns could be sold outside of the village. Therefore, because an owner could fully recover the value of his gun, there was no "destruction of the use and enjoyment of a legitimate private property right."'159 The same reasoning would apply if a state forbade firearm ownership. Thus, the right to sell might be sufficient to overcome the diminution of value test at the state level. A court might draw the line, however, at a federal ban on possession or ownership and consider the guns unsaleable, even if it were legal to transport firearms across international borders. Such a federal ban would thus be found to be a total diminution of value and would be a compensable taking under that test.

The third test which has been used is the police power test. If a state were to pass a law banning the possession of firearms, it could surely justify the act

157. Quilici v. Village of Morton Grove, 532 F. Supp. 1169, 1171 (N.D. Ill. 1981), affd. 695 F.2d 261 (7th Cir. 1982), cert. denied, 464 U.S. 863 (1983).

158. 369 U.S. 590, 592-93 (1962).

159. 532 F. Supp. at 1184 . 
under its police powers to punish crime and generally legislate for the health and safety of its citizens. Under cases like Fesjian v. Jefferson, ${ }^{160}$ Mugler $v$. Kansas, ${ }^{161}$ and Samuels v. McCurdy, ${ }^{162}$ which held that no compensation is required when a state law represents an exercise of the police power, such a state ban would not be a compensable taking. At the federal level, the "police power" test applies only by analogy. Under the rationale of the test, so long as an act can be characterized as pursuant to some power other than the eminent domain power, it need not be accompanied by compensation. ${ }^{163}$ Under this test, then, if federal firearm legislation were passed pursuant to the commerce or taxing powers, it would not be a compensable taking. (This test is applied here to federal legislation as part of a demonstrative exercise of the various taking tests, although such an application is, of course, illogical. Because there is no federal eminent domain power, all federal laws are passed under an enumerated power. Therefore, no federal law could ever require compensation under this theory.)

The final test which has been used is the noxious use test. Under this test, which is often coupled with the police power test, evil-avoidance legislation does not require just compensation. Thus, in Mugler $v$. Kansas, ${ }^{164}$ in which a lawfully operated brewery was closed under a prohibition statute which declared the brewery to be a public nuisance, the Court held that legislation to abate a nuisance was not a fifth amendment taking. ${ }^{165}$ This logic has also been applied to consumers. In Samuels v. McCurdy, ${ }^{166}$ McCurdy had a supply of liquor which was lawfully acquired before the state of Georgia banned its possession. Nevertheless, the Court upheld seizure as a valid exercise of state power to reduce the "evils of drunkenness." 167

By analogy, a state or federal government could declare all firearms or handguns in particular to be an evil to be avoided for the benefit of the public. Surely, if the presence of liquor in a community can be prohibited under a nuisance abatement theory, the threat of firearm deaths by accident or violence could support the declaration of firearms as a nuisance with equally strong justification. Thus, under the noxious use test, no compensation would be required for a confiscation of firearms.

It is clear from this summary that these tests reach contradictory results. The physical invasion and diminution in value tests point toward compensation, while the police power and noxious use tests point toward no compensation. Without a statement of how to resolve or balance the tests, it is impossible to resolve taking questions except in the "ad hoc" manner used

160. 399 A.2d 861 (D.C. 1979) (firearm legislation).

161. 123 U.S. 623 (1887) (liquor prohibition).

162. 267 U.S. 188 (1925) (liquor prohibition).

163. See Sax, supra note 5, at 36-37 n.6 (referring to the conflict between commerce clause regulations and fifth amendment takings as "parallel" to the police power-eminent domain distinction at the state level).

164. 123 U.S. 623 (1887)

165. Id. at 669 .

166. 267 U.S. $188(1925)$.

167. Id. at 198 . 
in Penn Central Transportation Co. v. City of New York. ${ }^{168}$ The three-part public use test, however, can be applied with more certainty. The following analysis describes how a federal or state ban would be analyzed under this test.

The first issue is whether the ban would result in an appropriation. Under this threshold inquiry, either an outright physical invasion or a significant diminution in value would constitute an appropriation. If the ban simply required all weapons to be turned in, it is clear that an appropriation would have occurred. Even in the absence of a physical transfer, however, the owners' property rights in their guns would be appropriated if the guns could not be kept at home, if they had to be rendered inoperative, or if they could not be possessed at all. As has been emphasized previously, such diminution in value is not dispositive of the taking issue. The continued adherence of the courts to the doctrine nevertheless represents a recognition that an affected property owner legitimately feels that something has been taken from him. It would be foolish not to concede that at least some portion of a gun owner's property in a firearm is appropriated when he cannot fire it. Unfortunately, from his point of view, this appropriation is not compensated because of the outcome of the remainder of this analysis.

The second issue is whether the ban would be a valid exercise of government authority. State firearm legislation could easily withstand scrutiny as a valid exercise of police power. This power would not be circumscribed by the second amendment, because that amendment has never been incorporated into the fourteenth amendment to bind the states. ${ }^{169}$

If a firearm ban were enacted at the federal level, it would have to be justified under one of the government's enumerated powers. Congress could, for example, find that the law was necessary to protect commerce because it would prevent robberies. This note expresses no opinion on the validity of that assumption, but presumes that a congressional finding to that effect would be sufficient to invoke the commerce clause. A federal firearm law would also have to be tested under the second amendment, but, as stated earlier, that analysis is not within the compass of this note. For our purposes, it is assumed that a federal ban would be upheld as a valid exercise of government power.

The final issue is whether the ban would be for public use as the term has been defined in this note. If the ban were passed in response to some kind of military emergency in which the government needed to give the confiscated weapons to the armed forces, the ban would clearly be an example of public use and require compensation. Such military use would be available only to the federal government. Theoretically, though, a state government could similarly confiscate firearms for the sole purpose of equipping its police force, for example. In that case, too, compensation would be required. Such examples are exceptions, however, to the ordinary intent of firearms

168. See 438 U.S. 104, 124 (1978).

169. United States v. Cruikshank, 92 U.S. 542, 553 (1876). See generally J. Nowak, R. Rotunda \& J. Young, supra note 42, at 413. 
legislation. Such laws would much more likely be passed for the purpose of ridding society of firearms and not because there is a public need to use the weapons. In fact, the weapons would probably be destroyed after seizure. In this more likely case, the public would benefit passively from the arguably safer society in which they would live. This benefit, however, is not public use as defined in this note and does not require compensation under the fifth amendment.

Thus, under the three-part public use test, no compensation would be required by the fifth amendment if there were a federal or state ban on the possession of firearms. Such a result may seem viscerally unfair; however, one must remember that if every regulation of property required compensation, a government would be unable to operate. More importantly, this result is dictated by the words of the Constitution. Under the analysis proposed in this note, that constitutional language is capable of a single, clear interpretation, which can guide courts to a rational treatment of the taking issue. 
